Illinois State University

ISU ReD: Research and eData

Theses and Dissertations

$10-9-2016$

\title{
Understanding Motivational Climate and Team Cohesion in Youth Sport
}

Annika M. Ewaldz

Illinois State University, annipi91@gmail.com

Follow this and additional works at: https://ir.library.illinoisstate.edu/etd

Part of the Kinesiology Commons, and the Psychology Commons

\section{Recommended Citation}

Ewaldz, Annika M., "Understanding Motivational Climate and Team Cohesion in Youth Sport" (2016).

Theses and Dissertations. 613.

https://ir.library.illinoisstate.edu/etd/613

This Thesis is brought to you for free and open access by ISU ReD: Research and eData. It has been accepted for inclusion in Theses and Dissertations by an authorized administrator of ISU ReD: Research and eData. For more information, please contact ISUReD@ilstu.edu. 


\title{
UNDERSTANDING MOTIVATIONAL CLIMATE AND \\ TEAM COHESION IN YOUTH SPORT
}

\author{
Annika M. Ewaldz
}

36 Pages

The effects of both peer-created and coach-created motivational climate on team cohesion was studied in a sample of 136 youth athletes. Task-involving aspects of both peer-and coach-created motivational climates were found to be positively related to team cohesion.

Coach-created ego-involving climate was negatively related to team cohesion, most significantly attraction to group-task (ATG-T) cohesion. Peer-created ego-involving motivational climate was significantly, negatively related to group integration-task (GI-T) cohesion. Peer-created motivational climate accounted for variance above and beyond the influence of coach-created motivational climate on team cohesion. No interactions were uncovered. The results of this study suggest that a peer-created motivational climate influences team cohesion above and beyond a coach-created motivational climate.

KEYWORDS: Motivational Climate, Cohesion, Youth Sports 


\section{UNDERSTANDING MOTIVATIONAL CLIMATE AND}

TEAM COHESION IN YOUTH SPORT

ANNIKA M. EWALDZ

A Thesis Submitted in Partial Fulfillment of the Requirements for the Degree of

MASTER OF SCIENCE

School of Kinesiology and Recreation

ILLINOIS STATE UNIVERSITY 
Copyright 2016 Annika M. Ewaldz 


\section{UNDERSTANDING MOTIVATIONAL CLIMATE AND}

TEAM COHESION IN YOUTH SPORT

ANNIKA M. EWALDZ

COMMITTEE MEMBERS:

Anthony Amorose, Chair

Peter Smith

Scott Pierce 


\section{ACKNOWLEDGMENTS}

This writer wishes to thank Tony Amorose, Pete Smith, Scott Pierce, Luke Wielgopolan, Brianna Todaro, Adina Ewaldz, Dave Ewaldz, and Elena Ewaldz.

A. M. E. 


\section{CONTENTS}

Page

ACKNOWLEDGMENTS

CONTENTS

$\begin{array}{ll}\text { TABLES } & \text { iii }\end{array}$

CHAPTER I: INTRODUCTION 1

$\begin{array}{lr}\text { CHAPTER II: METHOD } & 9\end{array}$

$\begin{array}{ll}\text { Participants } & 9\end{array}$

$\begin{array}{ll}\text { Procedure } & 9\end{array}$

$\begin{array}{ll}\text { Measures } & 10\end{array}$

$\begin{array}{ll}\text { Peer-Created Motivational Climate } & 10\end{array}$

$\begin{array}{ll}\text { Coach-Created Motivational Climate } & 10\end{array}$

Team Cohesion 11

Demographic Information $\quad 11$

$\begin{array}{ll}\text { Data Analysis } & 12\end{array}$

CHAPTER III: RESULTS 13

$\begin{array}{ll}\text { Preliminary Analyses } & 13\end{array}$

$\begin{array}{ll}\text { Main Analysis } & 13\end{array}$

CHAPTER IV: DISCUSSION 19

REFERENCES 23

APPENDIX A: SURVEY QUESTIONNAIRE 29 


\section{TABLES}

Table

Page

1. Descriptive Statistics and Correlations Among Study Variables $(N=136)$

2. Summary of Hierarchical Regression Analyses Predicting Dimensions of Cohesion

3. Results of the Final Regression Analyses Predicting Dimensions of Cohesion 


\section{CHAPTER I: INTRODUCTION}

In the climate of youth sports, there are many factors that influence how successful a team will be. The most notable influence for the purpose of this study is the interactions the athletes have with significant others, a person who is important to an individual's well-being. In the context of a team, every individual (including athletes, parents, and coaches) will have different goals for the team. The way that they approach these goals will have a significant affective influence on the individual and will contribute to how well teams will work together, since cohesion is important to team success. There are many factors that might influence team cohesion and one possibility involves significant others. This study was designed to look at one aspect of social influence, namely the motivational climate.

Motivational climate is defined as the situational goal structure of the team environment created by significant others (Ames, 1992). These significant others can be coaches, peers and parents. The motivational climate can be either task-involving or ego-involving. A taskinvolving climate is one where self-referenced criteria for success is emphasized. In other words, success and failure are evaluated based on effort and individual improvement. On the other hand, an ego-involving motivational climate is one which emphasizes normative ability to define success and failure. In this case, social comparison is the basis for evaluating achievement. Most often the motivational climate of teams is a combination of both task-involving and egoinvolving (Chi \& Duda, 1995; Duda \& Whitehead, 1998).

The majority of the research on motivational climate in sport team settings has focused on the motivational climate created by coaches. A task-involving coach-created motivational climate has been linked to more adaptive achievement patterns and more positive cognitive and emotional states (see Duda \& Balaguer, 2007). For instance, task-involving climates are 
associated with greater enjoyment, sport satisfaction and positive affect (Boixados, Cruz, Torregrosa \& Valiente, 2004; Carpenter \& Morgan, 1999; Ntoumanis \& Biddle, 1999; Seifriz et al., 1992; Treasure, 1993; Vazou, Ntoumanis \& Duda, 2005; Walling et al., 1993), increased use of adaptive coping strategies (i.e. problem solving) (Kim \& Duda, 1998), a lower probability of burnout (Duda, Balaguer, Moreno \& Crespo, 2001), higher perceptions of competence (Boixados et al., 2004; Reinboth, Duda \& Ntoumanis, 2004), increased collective efficacy (Kao \& Watson, 2014), a belief that success is obtained mostly through effort (Seifriz et al., 1992; Treasure, 1993), higher self reports of performance and improvement (Balaguer, Duda \& Crespo, 1999; Pensgaard \& Duda, 2004), and a higher objective competitive performance (Pensgaard \& Duda, 2004). Whereon the other hand, participation in an ego-involving coach-created motivational climate generally results in more negative or maladaptive outcomes. For example, an egoinvolving coach-created motivational climate has been linked to higher reported anxiety, and more specifically performance-related anxiety (Ntoumanis \& Biddle, 1999; Papaionnou \& Kouli, 1999; Pensgaard \& Roberts, 2002; Walling et al., 1993), greater amounts of conflict with peers (Ommundsen et al., 2005), and perceiving one's ability as a reference to others' ability (Boixados et al., 2004).

Just as coaches can influence the definition of success emphasized in the environment, peers do as well and researchers have recently started to study their impact on the motivational climate. Ntoumanis, Vazou, and Duda (2007) argued that peer use of criteria for judging competence and inferring success and failure can predict young athletes' achievement motivation relatively independent of coach or parent influence. The research on the outcomes associated with the peer-created motivational climate has found generally the same pattern as the coachcreated motivational climate; more positive outcomes related to a task-involving motivational 
climate and more negative outcomes associated to an ego-involving motivational climate. For example, a task-involving peer-created motivational climate has been linked to higher physical self-esteem, sport enjoyment, and sport commitment (Ntoumanis, Vazou \& Duda, 2007). On the other hand, an ego-involving peer-created motivational climate has been linked to higher levels of anxiety (Carr, Weigand, \& Hussey, 1999), greater amounts of conflict with peers (Vazou, Nroumani \& Duda, 2005), and lower self-esteem (Reinboth and Duda, 2004).

Given that coaches and peers are in the sport context together it makes sense to see how they can influence the motivational climate simultaneously. A couple of studies have researched that link (Vazou, Ntoumanis \& Duda, 2006; Ntoumanis, Taylor \& Thøgersen-Ntoumani 2012). Vazou and colleagues (2006) studied the effects of peer- and coach-created motivational climates on physical self-esteem, enjoyment, competitive trait anxiety, and sport commitment in 30 British youth athletes. They found that a task-involving peer-created motivational climate was a significant positive predictor of physical self-esteem, enjoyment, and sport commitment. A taskinvolving coach-created motivational climate was a significant positive predictor of enjoyment and effort. An ego-involving coach-created motivational climate was a significant positive predictor of physical trait anxiety.

Ntoumanis, Taylor, and Thøgersen-Ntoumani (2012) studied perceptions of coach and peer motivational climates and how these perceptions predicted moral attitudes, emotional wellbeing, and indices of behavioral investment. They adopted a longitudinal examination in a sample of British adolescent athletes ages 12-16, participating in soccer, basketball, or rugby. Measures were taken at the beginning, middle, and end of each sport's competitive season. Generally they found that more adaptive or positive outcomes were predicted by perceptions of task-involving peer and coach-created climates. On the other hand, both peer and coach-created 
ego-involving climates predicted less adaptive and more negative outcomes. A few examples include: (a) high perceptions of peer-created ego-involving motivational climate predicted high levels of gamesmanship and other antisocial attitudes, (b) a high peer-created task-involving motivational climate predicted high levels of pro-social attitudes, specifically respect for convention, (c) a peer-created task-involving climate negatively predicted burnout, (d) a coach created ego-involving climate positively predicted burnout, (e) a high ego-involving peer climate predicted lower effort ratings, and (f) a coach created ego-involving climate negatively predicted the change that the athletes would return to their sport club for the next season. This study assessed many possible outcomes of both coach and peer created motivational climates, but there are other potential achievement-related outcomes, which might be influenced by the motivational climate.

Previous motivational climate research, whether coach or peer-created, has focused mostly on individual athlete outcomes associated with experiencing different climates, such as perceived competence (Boixados, Cruz, Torregrosa \& Valiente, 2004; Reinboth, Duda \& Ntoumanis, 2004), enjoyment (Vazou, Ntoumanis, and Duda, 2006; McAuley, Duncan, \& Tammen, 1989; Carr et al., 1999; Boixados, et al., 2004; Carpenter \& Morgan, 1999; Ntoumanis \& Biddle, 1999; Seifriz et al., 1992; Treasure, 1993; Vazou, Ntoumanis \& Duda, 2005, Walling et al., 1993), and burnout (Duda, Balaguer, Moreno \& Crespo, 2001). While there has been an array of work done on individual athlete outcomes of motivational climate, the motivational climate can also influence team or group level outcomes, such as peer relationships (Ommundsen, Roberts, Lemyre, \& Miller, 2005), peer conflict (Ommundsen et al., 2005), and ratings of the team's cohesion. I am specifically interested in more team outcomes, namely team cohesion. 
Team cohesion is defined as "a dynamic process which is reflected in the tendency for a group to stick together and remain united in pursuit of its instrumental objectives and/or for the satisfaction of member affective needs" (Carron, Brawley \& Widmeyer, 1998, p. 213). Team cohesion is broken down into categories of group integration, which is measured by an individual's perceptions of closeness and similarity to the team and the degree to which the team is unified, and individual attractions to the group, which is described as the personal motivations acting to attract and to retain the athlete in the team (Carron, Eys, \& Burke, 2007). Both of these types are broken down further as either task (perceptions of achieving the group's objectives) or social (an orientation toward making and maintaining relationships with teammates), making four categories of team cohesion: group integration-task (GI-T), group integration-social (GI-S), individual attractions to the group-task (ATG-T), and individual attractions to the group-social (ATG-S) (Carron, Eys, \& Burke, 2007). Group integration-task is the perception of team unification of reaching the team's goals. Group integration-social cohesion is the closeness and unification toward making and maintaining social relationships within the team. Individual attractions to the group-task orientation is defined as the perception that achieving the team's objectives is what attracts and retains athletes to the group. Individual attractions to the groupsocial is the perception that developing and maintaining social relationships with teammates and social activities is what attracts and retains athletes to the team.

It has been found that if team members perceive high levels of cohesion (in both task and social aspects), it is expected that the team would agree with and conform to standards of behavior that are deemed acceptable for that group (Carron, Eys \& Burke, 2007; Prapavessis \& Carron, 1997). Also, many benefits of high levels of cohesion have been found, such as higher perceived collective efficacy (Zaccaro, Blair, Peterson, \& Zazanis, 1995), clear consistent 
information regarding one's role on the team (Kahn, Wolfe, Quin, Snoek, \& Rosenthal, 1964; Eys \& Carron, 2001), lower cognitive state anxiety (Prapavessis \& Carron, 1996; Eys, Hardy, Carron, \& Beauchamp, 2003), reduced social loafing (McKnight, Williams, \& Widmeyer, 1991) and increased effort (Bray \& Whaley, 2001). Given these benefits, finding ways to enhance cohesion should be valuable to those involved in sport teams and organizations. While there are many possibilities, one strategy may be to alter the motivational climate.

Motivational climate and cohesion both deal with the individual athlete's perceptions of their team and involve an affective component (Carron et al., 1998). Due to the dependence on the social aspects of cohesion and motivational climate, theoretically there should be links between motivational climate and team cohesion and a handful of studies have demonstrated this link (Boyd et al., 2014, Eys et al., 2013, Garcia-Calvo et al., 2014, Heuze et al., 2006, Horn et al., 2012). The existing research linking motivational climate and team cohesion have found a fairly consistent pattern of relationships. Specifically, teams with high levels of task-involving motivational climate and low levels of ego-involving motivational climate have been linked to high levels of team cohesion. For example, Heuze et al. (2006) studied these relationships in 124 elite, female basketball and handball players in France. They found that perceptions of a highego involving climate in combination with low perceptions of a task-involving climate was linked to low perceptions of both types of task cohesion (GI-T and ATG-T). On the other hand, high perceptions of a task-involving climate combined with low perceptions of an ego-involving climate was associated with higher perceptions of task cohesion (GI-T and ATG-T).

One limitation of most of the research in this area is that studies have focused fairly exclusively on the coach-created motivational climate. Only one study that I know of has looked at coach and peer created motivational climate and how they contribute to team cohesion. This 
study by Garcia-Calvo et al. (2014) looked at male semi-professional soccer players from Spain. The athletes completed measures of coach- and peer-created motivational climate and team cohesion at beginning, middle, and end of a season. They used multilevel modeling to explore whether between-person differences in perceptions of the climate dimensions predicted withinperson changes in cohesion. Their results generally found that both coach- and peer-created task-involving motivational climate to be significant and positive predictors of cohesion. Also, they found that peer-created motivational climate contributed above and beyond the effect of the coach-created motivational climate.

One of the more unique and interesting findings of the Garcia-Calvo et al. study came from the testing of interactions among the different types of motivational climates. Analyses at the intrapersonal level revealed a few significant interactions, namely peer-task $\mathrm{x}$ peer-ego predicting GI-T and peer-task x coach-task predicting ATG-T. When they probed the peer-task by peer-ego interaction they found that the relationship between the peer-created task climate and GI-T was weaker among athletes who perceived higher compared to lower peer-created ego climate. When they probed the peer-task by coach-task interaction they found that the coachcreated task climate positively predicted ATG-T when the peer-created task climate was high, but it was non-significant when the peer-created task climate was low. Thus, there is at least initial evidence that a more complete understanding of the effects of the motivational climate on group cohesion may come from exploring the interactions of the different types of climate functioning in the environment.

In summary, the majority of the previous research on motivational climate and team cohesion has focused mostly on coach-created motivational climate. Furthermore, only one study has studied the interactions between peer-created motivational climate and coach-created 
motivational climate on team cohesion (Garcia-Calvo et al., 2014), and this study had a sample which only included semi-professional soccer players in Spain, thus limiting the generalizability of the results. Therefore, the goal of this study was to extend the literature by exploring the possible interactions with a different and more diverse sample of athletes. Specifically, the purpose of this study was to look at the influence of the coach-created motivational climate and peer-created motivational climate on team cohesion. This involved testing: (a) testing whether the peer-created motivational climate predicts aspects of team cohesion above and beyond the influence of coach-created motivational climate in youth athletes, and (b) whether the interactions between motivational climate dimensions and between coaches and peers add to the predictions of team cohesion.

I hypothesized that a task-involved coach and peer-created motivational climate would positively predict team cohesion dimensions, whereas an ego-involved coach and peer-created motivational climate would negatively predict team cohesion. Also, I hypothesized that a peercreated motivational climate would add to the prediction of coaches above and beyond the influence of the coach-created motivational climate. Finally, I expected that interactions among climate dimensions would also predict cohesion, but the exact pattern was unclear. 


\section{CHAPTER II: METHOD}

\section{Participants}

Participants were recruited through coaches, athletic directors, teachers, and principals of local schools and athletic clubs. The final sample consisted of 136 youth athletes (49 males, 87 females, Mage $=16.24, \mathrm{SD}=1.23$, age range: $11-18$ years $)$ from basketball $(\mathrm{n}=75)$, volleyball $(n=8)$, baseball $(n=23)$, soccer $(n=11)$, and softball $(n=19)$ teams. Athletes were from high school, middle school, or club sports teams, with $69.9 \%$ of the athletes having played for male coaches $(n=95)$ and $30.1 \%$ of athletes having played for female coaches $(n=41)$. Athletes reported playing for their coaches for a mean of 1.69 years $(\mathrm{SD}=.997)$ and reported playing their sport for a mean of 8.62 years $(\mathrm{SD}=3.09$, range $=1$ to 15 years $)$. Self-reported race/ethnicity of the participants was as follows: 11 African American (8.1\%), 7 Hispanic (5.1\%), 1 Native American $(0.7 \%), 116$ Caucasian $(85.3 \%)$, and 1 who identified their race as 'other' $(0.7 \%)$.

\section{Procedure}

Researchers asked athletic directors and coaches from around the Midwest to participate in a survey for this study and times to meet with their teams were set up. During an initial meeting the athletes were given a parent letter and a parent permission letter to bring home to their parents/guardians. The athletes were told that the research was to study why young athletes choose to participate in sports and to explore the social interactions between teammates and coaches contributing to effectiveness of teams. About a week later, a researcher returned and collected the permission forms and administered the survey. The researcher administering the survey explained to the students that the survey will take about 20-30 minutes. The researcher then gained athlete assent and asked all coaches and parents to the leave the duration of the survey before administering the surveys. 


\section{Measures}

\section{Peer-Created Motivational Climate}

The Peer Motivational Climate in Youth Sport Questionnaire (PeerMCYSQ) (Vazou et al., 2005) was used to assess the athletes' perceptions of the motivational climate on their team created by their peers. The PeerMCYSQ is a 21 -item questionnaire that assesses the individual dimensions of a task involving (improvement, relatedness support, and effort) and an egoinvolving climate (intrateam competition and ability and intrateam conflict). Items are ranked using a 5-point Likert-type scale, ranging (1) strongly disagree to (5) strongly agree. The questions began as "On this team, most athletes..." An example of an item measuring taskinvolvement is "On this team, most athletes offer to help their teammates develop new skills." An example item that measures ego-involvement and ability asks: "On this team, most athletes try to do better than their teammates." Ntoumanis and Vazou (2005) have reported initial evidence supporting the reliability and validity of the measure.

\section{Coach-Created Motivational Climate}

The athletes were given the 33-item Perceived Motivational Climate in Sport Questionnaire (PMSCQ-2) (Newton, Duda, \& Yin, 2000) to assess their perceptions of the coach-created motivational climate. The PMSCQ-2 assess the following dimensions of a taskinvolving climate: cooperative learning, effort and improvement, and important roles and the following aspects of an ego-involving climate: intra-team rivalry, unequal recognition, and punishment for mistakes. On the PMSCQ-2 the athletes are asked to rate how much they personally agree with the statements. An example of an item measuring task-involving coachcreated motivational climate is: "On this team, players help each other learn." An example of an item assessing an ego-involving coach-created motivational climate asks: "On this team, only the 
top players 'get noticed' by the coach." The athletes responded to the various items on a Likerttype scale ranging from (1) strongly disagree to (5) strongly agree. Initial evidence of the reliability and validity for the PMCSQ-2 was reported by Newton et al. 2000.

\section{Team Cohesion}

The Group Environment Questionnaire (GEQ) was used to assess the athletes' perceptions of team cohesion (Carron et al., 1985). The GEQ is an 18 -item scale that assess the four dimensions of group cohesion (Group Integration-Task (GI-T), Group Integration-Social (GI-S), Individual Attraction to Group-Task (ATG-T), and Individual Attraction to Group-Social (ATG-S)). The GI-T and GI-S subscales are formulated as 'our' and 'we' responses, whereas the ATG-T and the ATG-S questions are formulated as 'I' or 'me'. The answers are on a 9-point Likert-type response scores ranging from (1) strongly disagree to (9) strongly agree. An example of an item assessing ATG-T asks: "I am unhappy with my team's level of desire to win" (reverse scored). An example of an item measuring ATG-S is: "Some of my best friends are on this

team." An example of an item measuring GI-T is: "Our team is united in trying to reach its goals for performance." Finally, an example of an item measuring GI-S is: "Our team would like to spend time together in the off season." The reliability and validity of the instrument has been documented by Carron, Eys, and Martin (2012).

\section{Demographic Information}

Athletes were asked to answer simple demographic information such as age, gender, race, sport, length of time participating in sport, length of time they have been a member of their current team, how long they have played for their current coach, and the gender of their coach. 


\section{Data Analysis}

A series of hierarchical multiple regressions were used to test the main research questions. Specifically, regression analyses were used to determine which motivational climate dimensions positively or negatively predict cohesion and to determine if the peer-created climate and any possible interactions contribute above and beyond the well documented effect of the coach created-created motivational climate. 


\section{CHAPTER III: RESULTS}

\section{Preliminary Analyses}

The descriptive statistics and correlations for the study variables are presented in Table 1. The internal consistency estimates $(\alpha)$ for the measures ranged from .68 to .92., indicating acceptable reliability (DeVellis, 2012). Mean scores on all measures were above the midpoint of the respective scales, although the ego-involved climate created by both coaches and peers were very near the midpoint. As a way to further describe the data, a MANOVA was conducted to explore whether there were any gender differences in the set of variables. Results revealed significant difference, Wilk's $\lambda(8,127)=3.49, \mathrm{p}<.01, \eta 2=.18$. An examination of the univariate $\mathrm{F}$ values indicated the only significant difference between the female and male participants was their perceptions of the peer-created ego-involved climate, $\mathrm{F}(1,135)=6.53, \mathrm{p}<$ $.01, \eta 2=.06$, with the females reporting lower scores.

The bivariate correlations revealed there were significant positive relationships between the task-involved motivational climates and the various dimensions of cohesion, whereas the peer-created ego-involved climate was significantly and negatively related (see Table 1). The coach-created ego-involved climate was not significantly related to any of the climate dimensions.

\section{Main Analysis}

First, we evaluated the key assumptions for multiple regression analyses (e.g., normality, linearity, and homoscedasticity of residuals; absences of multicollinearity and singularity, absences of multivariate outliers) as outlined by Tabachnick and Fidell (2013). No violations were noted, and therefore we proceeded to test the primary research question with a series of hierarchical regression analyses. A separate analysis was used to examine each of the four 
dimensions of cohesion, as well as an overall cohesion score (calculated as a mean of the four specific dimensions). In each analysis, the coach-created motivational climate dimensions were entered on Step 1, followed by the two peer-created climate dimensions on Step 2. The interaction between the coach-created task and ego-involved climate dimensions and the interaction between the peer-created task and ego-involved dimensions were entered on Step 3. Finally, the coach-created and peer-created task-involved climate interaction and the coachcreated and peer-created ego-involved interaction were added on Step 4. Consistent with the recommendations of Aiken and West (1991), the predictor variables were centered and the interaction terms were formed as the cross-product of the centered variables.

A summary of these analyses is presented in Table 2 . The results showed that the independent effects of coach-created motivational climate dimensions entered together on Step 1 of the equations significantly $(\mathrm{p}<.05)$ predicted each of the variables, with $\mathrm{R} 2$ values ranging from .27-.47. The addition of the peer-created climate dimensions on Step 2 also significantly $(p<.05)$ added to the prediction of cohesion in each of the analyses, although the prediction of ATG-Task was only marginally significant $(\mathrm{p}<.09)$. The amount of additional variance explained by the addition of the peer-created climate dimensions ranged from relatively low for the two ATG dimensions $\left(\Delta R^{2}\right.$ for ATG - Task $=.02, \Delta R^{2}$ for ATG - Social $\left.=.04\right)$, but was more larger for the two GI dimensions $\left(\Delta R^{2}\right.$ for GI - Task $=.17, \Delta R^{2}$ for GI - Social $\left.=.12\right)$ and overall cohesion $\left(\Delta R^{2}=.11-.17\right)$. None of the interactions entered on Step 3 or Step 4 significantly added to the prediction of cohesion in any of the analyses.

Given these findings, it was deemed most appropriate to interpret the regression equations where the predictors included the two coach-created and two peer-created climate dimensions (i.e., the regression equations including Step 2). Table 3 includes the main results of 
these analyses. Examination of the standardized regression coefficients $(\beta)$ revealed that the motivational climate dimensions, for the most part, predicted the cohesion dimensions in the expected directions. For example, the two task-involved climate dimensions were significant, positive predictors of cohesion in each of the analyses, with the lone exception of the effect of the coach-created task-involved climate being non-significant predictor of GI - Social. As expected, in most cases the ego-involved climate dimensions were negative predictors of coaches; however, the effects were significant in only a few of the analyses (i.e., GI - Task, ATG - Task, overall cohesion).

Based on the size of the standardized regression coefficients $(\beta)$ and the squaredsemipartial correlations (sr2), which indicates the amount of unique variance accounted for by each predictor variable, the relative strength of the relationships between the climate and cohesion dimensions revealed that the task-involved dimensions had a stronger influence on cohesion (see Table 3). Further, it appears that the peer-created climate tended to account for more of the unique variation in the GI dimensions of cohesion, whereas the coach-created climate accounted for more variation in the ATG dimensions of cohesion. As an example, peercreated task-involved climate had a relatively stronger independent effect on GI - Task $(\beta=.53$; $\mathrm{sr} 2=.24)$ relative to the coach-created task-involved climate $(\beta=.20 ; \mathrm{sr} 2=.03)$. Conversely, the unique effect of coach-created task-involved climate was relatively larger in the prediction of ATG - Social $(\beta=.40 ; \mathrm{sr} 2=.09)$ relative to peer-created task-involved climate $(\beta=.29 ; \mathrm{sr} 2=.01)$. 
Table 1

Descriptive Statistics and Correlations Among Study Variables $(N=136)$

\begin{tabular}{|c|c|c|c|c|c|c|c|c|}
\hline Variable & 1. & 2. & 3. & 4. & 5. & 6. & 7. & 8. \\
\hline 1. GI - Task & -- & & & & & & & \\
\hline 2. GI - Social & $.60^{*}$ & -- & & & & & & \\
\hline 3. ATG - Task & $.56^{*}$ & $.41^{*}$ & -- & & & & & \\
\hline 4. ATG - Social & $.44^{*}$ & $.50^{*}$ & $.60 *$ & -- & & & & \\
\hline $\begin{array}{l}\text { 5. Coach-created task- } \\
\text { involved climate }\end{array}$ & $.61^{*}$ & $.44 *$ & $.57 *$ & $.51 *$ & -- & & & \\
\hline $\begin{array}{l}\text { 6. Coach-created ego- } \\
\text { involved climate }\end{array}$ & .12 & .07 & .01 & .11 & $.39 *$ & -- & & \\
\hline $\begin{array}{l}\text { 7. Peer-created task- } \\
\text { involved climate }\end{array}$ & $.72 *$ & $.56^{*}$ & $.52 *$ & $.50 *$ & $.69 *$ & $.19 *$ & -- & \\
\hline $\begin{array}{l}\text { 8. Peer-created ego- } \\
\text { involved climate }\end{array}$ & $-.43 *$ & $-.28 *$ & $-.19 *$ & $-.19 *$ & -.38 & $.24 *$ & $-.39 *$ & -- \\
\hline Mean & 6.54 & 5.63 & 6.91 & 7.19 & 4.22 & 3.68 & 5.55 & 3.88 \\
\hline Standard Deviation & 1.46 & 1.70 & 1.78 & 1.53 & .53 & .38 & .91 & .92 \\
\hline Cronbach alpha $(\alpha)$ & .73 & .69 & .70 & .68 & .90 & .91 & .92 & .75 \\
\hline
\end{tabular}

Note. $*$ indicates a significant correlation at $p<.05$. 
Table 2

Summary of Hierarchical Regression Analyses Predicting Dimensions of Cohesion

\begin{tabular}{|c|c|c|c|c|}
\hline Regression & $F$ & $R^{2}$ & $\Delta R^{2}$ & $p$ value for $\Delta F$ \\
\hline \multicolumn{5}{|l|}{ GI-Task } \\
\hline Step 1 & 41.52 & .38 & -- & .00 \\
\hline Step 2 & 25.81 & .56 & .17 & .00 \\
\hline Step 3 & .00 & .56 & .00 & .99 \\
\hline Step 4 & 1.40 & .57 & .01 & .25 \\
\hline \multicolumn{5}{|l|}{ GI-Social } \\
\hline Step 1 & 17.17 & .21 & -- & .00 \\
\hline Step 2 & 11.92 & .33 & .12 & .00 \\
\hline Step 3 & 1.30 & .34 & .01 & .28 \\
\hline Step 4 & .47 & .35 & .01 & .63 \\
\hline \multicolumn{5}{|l|}{ ATG-Task } \\
\hline Step 1 & 40.21 & .38 & -- & .00 \\
\hline Step 2 & 2.41 & .40 & .02 & .09 \\
\hline Step 3 & .77 & .41 & .01 & .47 \\
\hline Step 4 & .40 & .41 & .00 & .67 \\
\hline \multicolumn{5}{|l|}{ ATG-Social } \\
\hline Step 1 & 24.22 & .27 & -- & .00 \\
\hline Step 2 & 4.21 & .31 & .04 & .02 \\
\hline Step 3 & .48 & .32 & .01 & .62 \\
\hline Step 4 & .72 & .32 & .01 & .49 \\
\hline \multicolumn{5}{|c|}{ Overall Cohesion } \\
\hline Step 1 & 59.24 & .47 & -- & .00 \\
\hline Step 2 & 17.77 & .58 & .11 & .00 \\
\hline Step 3 & .80 & .59 & .01 & .45 \\
\hline Step 4 & .87 & .60 & .01 & .42 \\
\hline
\end{tabular}

Note. Step 1 = coach-created climate variables, Step 2 = addition of peer-created climate variables, Step 3 = addition of coach-created task and ego climate and peer-created task and ego climate interactions, Step $4=$ addition of interactions between coach and pee-created climate variables. 


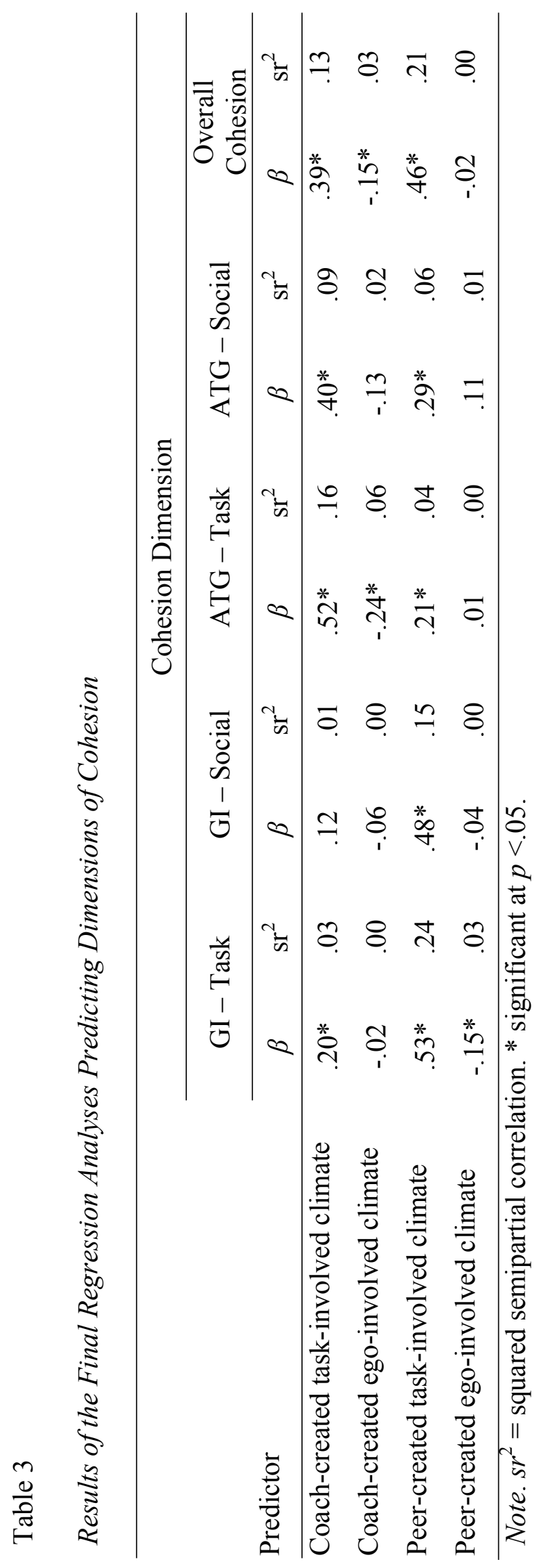




\section{CHAPTER IV: DISCUSSION}

The purpose of this study was to examine the effects of motivational climate on team cohesion in youth sports, specifically to study the effects that peer-created motivational climate and coach-created motivational climate have on team cohesion in youth sports. I hypothesized that a task-involved coach and peer-created motivational climate would positively predict dimensions of team cohesion, while an ego-involved coach and peer-created motivational climate would negatively predict dimensions of team cohesion.

Consistent with expectations, the results indicated that both peer- and coach-created taskinvolving motivational climates positively predicted team cohesion dimensions. Also, a coachcreated ego-involving climate was always negatively related to cohesion, and was significant for ATG task and overall cohesion. On the other hand, peer-created ego-involving climate was negatively related to cohesion in some cases and positively related to cohesion in others, although the only significantly result was in the prediction of GI-task, where it was negatively related. This general pattern of relationships is consistent with Garcia-Calvo et al. (2014).

As the majority of previous research has focused on how a coach-created motivational climate contributes to team cohesion and that coaches are not the only significant other in the context of a team, I hypothesized that a peer-created motivational climate would predict team cohesion above and beyond the influence of coach-created motivational climate. This hypothesis was supported and generally I found that a peer-created motivational climate accounted for variance above and beyond the influence of coach-created motivational climate. In regards to overall cohesion, a peer-created motivational climate predicted about $11 \%$ more of the variance than the coach-created motivational climate. The peer-created motivational climate added significantly to all dimensions, expect ATG-task. It was clear based on the change in R2 that the 
addition of the peer climate was particularly influential for the GI dimensions of cohesion. Interestingly, we found that a peer-created motivational climate accounted for more of the variance for GI aspects of cohesion, whereas a coach-created motivational climate accounted for more of the variance for ATG aspects of cohesion. These were unique findings of this study and further research is required to uncover why this pattern of results emerged.

Finally I hypothesized that the interactions among climate dimensions would also predict cohesion. Unfortunately, I found no support for this hypothesis. Garcia-Calvo et al. (2014) found significant results in regards interactions among motivational climate dimensions predicting cohesion. For example, a peer-task $\mathrm{x}$ peer-ego interaction predicting GI-T and a peer-task $\mathrm{x}$ coach-task interaction predicting ATG-T. When they probed the peer-task by peer-ego interaction, they found that the relationship between the peer-created task climate and GI-T was weaker among athletes who perceived higher compared to a lower peer-created ego climate. Then when they probed the peer-task by coach-task interaction they found that the coach-created task climate positively predicted ATG-T when the peer-created task climate was high, but it was non-significant when the peer-created task climate was low. No significant interactions were found in the current study, however.

One possible explanation for the lack of support for the interactions in this study involves the size of the sample. The initial goal was to survey 200-300 athletes, but I fell short of this and ended up with a sample size of only 136 athletes. This small sample size ultimately affects the power of the study and may have limited the ability to uncover significant interactions. This is clearly a limitation of the study.

Another possible explanation may be that the pattern of results is different across different types of athletes. The interactions found in the Garcia-Calvo et al. (2014) were based on 
data reported by semi-professional male soccer players from Spain. The current study included only high school athletes from the Midwestern portion of the Untied State of America. Also, the current sample included athletes from multiple team sports. Perhaps these differences account for the inconsistent pattern of results.

Future research should continue to explore the interactions between climate dimensions and their possible prediction of cohesion. In the future, a larger sample size will be necessary to increase the power of the results and to see if there are indeed any interactions between climate dimensions. Studies should also explore whether various athlete characteristics might moderate the pattern of relationships. It would also be interesting to do a longitudinal study (i.e. test peerand coach-created motivational climate and cohesion measurements at different points of the season) to test if peer-created motivational climate contributes more in a certain part of a competitive season.

In conclusion, this study added significantly to the existing literature in this area in a number of ways. First, the results show that the climate is clearly related to cohesion. Motivational climate and team cohesion conceptually should be related due to the impact of significantly others on the goal structure of the team and the unity of the team to achieve these goals. Second, generally speaking, both coaches and peers contribute to the climate of the team. This supports some of the previous research and reinforces the idea that multiple social influences may contribute to team outcomes.

Practical implications provide some insight into how motivational climates should be arranged to provide the most cohesive teams. Generally speaking, a motivational climate that is high in both peer- and coach-created task and low in both peer- and coach-created ego-involving are generally the most cohesive. In regards to making the motivational climate more task- 
involving rather than ego-involving, previously efforts have focused on effective coaching strategies. This study shows the importance for the athletes themselves to learn about motivational climate and focus on team building. Some examples of team building that can foster a task-involving peer-created motivational climate include: teammates working together to learn or practice skills, organizing social events for all players, and the team encouraging athletes to encourage their peers' achievements. This is important because it is becoming more evident that peers contribute to the motivational climate above and beyond coaches. 


\section{REFERENCES}

Aiken, L. S., \& West, S. G. (1991). Multiple regression: Testing and interpreting interactions. Newbury Park: Sage.

Ames, C. (1992). Classrooms: Goals, structures, and student motivation. Journal of Educational Psychology, 84(3), 261-271.

Balaguer, I., Duda, J. L., \& Crespo, M. (1999). Motivational climate and goal orientations as predictors of perceptions of improvement, satisfaction and coach rating among tennis players. Scandinavian Journal of Medicine and Science in Sports, 9, 381-388.

Boixados, M., Cruz, J., Torregrosa, M., \& Valiente, L. (2004). Relationships among motivational climate, satisfaction, perceived ability, and fair play attitudes in young soccer players. Journal of Applied Sport Psychology, 16(4), 301-317.

Boyd, M., Kim, M., Ensari, N., \& Yin, Z. (2014). Perceived motivational team climate in relation to task and social cohesion among male college athletes. Journal of Applied Social Psychology, 44, 115-123.

Bray, C. D., Whaley, D.E. (2001). Team cohesion, effort, and objective individual performance of high school basketball players. Sports Psychology, 15, 260-275.

Carpenter, P.J., \& Morgan, K. (1999). Motivational climate, personal goal perspective, and cognitive and affective responses in physical education classes. European Journal of Physical Education, 4, 31-44.

Carr, S., Weigand, D. A., \& Hussey, W. (1999). The relative influence of parents, teachers, and peers on children and adolescents' achievement and intrinsic motivation and perceived competence in physical education. Journal of Sport Pedagogy, 5, 28-50. 
Carron, A. V. Brawley, L. R., \& Widmeyer, W. N. (1985). The development of an instrument to measure cohesion in sport teams: The Group Environment Questionnaire. Journal of Sport Psychology, 7, 244-266.

Carron, A.V., Brawley, L.R., \& Widmeyer, W.N. (1998). The measurement of cohesiveness in sport groups. In J.L. Duda (Ed.), Advances in sport and exercise psychology measurement. Morgantown, WV: Fitness Information Technology.

Carron, A., Eys, M., \& Burke, S. (2007). Team cohesion: Nature correlates, and development. In Jowett, S. \& Lavellee, D (Eds.), Social Psychology in Sport (pp. 91-101). Champaign, IL:Human Kinetics.

Carron, A., Eys, M., \& Martin, L. (2012). Cohesion. In G. Tenenbaum, R. C. Eklund and A. Kamata (Eds.), Measurement in sport and exercise psychology (pp. 411-421). Champaign, IL: Human Kinetics.

Chi, L., \& Duda, J. (1995). Multi-sample confirmatory factor analysis of the task and ego orientation in sport questionnaire. Research Quarterly for Exercise and Sport, 66(2), 9198.

DeVellis, R.F. (2012). Scale development: Theory and applications. Los Angeles, CA: Sage.

Duda, J \& Balaguer, I. (2007). Coach-created motivational Climate. In Jowett, S. \& Lavellee, D (Eds.), Social Psychology in Sport (117-130). Champaign, IL: Human Kinetics.

Duda, J., Balaguer, I., Moreno, Y., \& Crespo, M. (2001). The relationship of the motivational climate and goal orientations to burn-out among junior elite tennis players. Paper presented at the meetings of AAASP, Orlando, FL. 
Duda, J. L., \& Whitehead, J. (1998). Measurement of goal perspectives in the physical domain. Advances in sport and exercise psychology measurement, 21-48.

Eys, M. A., \& Carron, A. V. (2001). Role ambiguity, task cohesion, and task self efficacy. Small Group Research, 32, 356-373.

Eys, M. A., Hardy, J., Carron, A. V., \& Beauchamp, M. R. (2003). The relationship between task cohesion and competitive state anxiety. Journal of Sport \& Exercise Psychology, 25, 66-76.

Eys, M., Jewitt, E., Evans, M., Wolf, S., Bruner, M., \& Loughead, T. (2013). CoachInitiated Motivational Climate and Cohesion in Youth Sport. Research Quarterly for Exercise and Sport, 84(3), 373-383.

García-Calvo, T., Leo, F. M., Gonzalez-Ponce, I., Sánchez-Miguel, P. A., Mouratidis, A., \& Ntoumanis, N. (2014) Perceived coach-created and peer-created motivational climates and their associations with team cohesion and athlete satisfaction: evidence from a longitudinal study, Journal of Sports Sciences, 32:18, 1738-1750, DOI: $10.1080 / 02640414.2014 .918641$

Heuzé, J., Sarrazin, P., Masiero, M., Raimbault, N., \& Thomas, J. (2006). The Relationships of Perceived Motivational Climate to Cohesion and Collective Efficacy in Elite Female Teams. Journal of Applied Sport Psychology, 18, 201-218.

Horn, T., Byrd, M., Martin, E., \& Young, C. (2012). Perceived Motivational Climate and Team Cohesion in Adolescent Athletes. Sport Science Review, 21, 25-49.

Kahn, R. L., Wolfe, D. M., Quinn, R. P., Snoek, J. D., \& Rosenthal, R. A. (1964). Organizational stress: Studies in role conflict and ambiguity. New York: Wiley. 
Kao, S., \& Watson, J. (2014). The multilevel effects of motivational climate on the collective efficacy in a cheerleading team. International Journal of Sports Science \& Coaching, 9, 593-603.

Kim, M. S., \& Duda, J. L. (1998). Achievement goals, motivational climate, and occurrence of and response to psychological difficulties and performance debilitation among Korean athletes. Journal of Sport and Exercise Psychology, 20, S124.

McAuley, E., Duncan, T., \& Tammen, V. V. (1989). Psychometric properties of the Intrinsic Motivation Inventory in a competitive sport setting: A confirmatory factor analysis. Research Quarterly for Exercise and Sport, 60, 48-58.

McKnight, P., Williams, J.M., \& Widmeyer, W.N. (1991, October). The effects of cohesion and identifiability on reducing the likelihood of social loafing. Presented at the Association for the Advancement of Applied Sport Psychology Conference, Savannah, GA.

Newton, M., Duda, J.L., \& Yin, Z. (2000) Examination of the psychometric properties of the perceived motivational climate in sport questionnaire 2 in a sample of female athletes. Journal of Sport Sciences, 18, 275-290.

Ntoumanis, N. \& Biddle, S. (1999). Affect and achievement goals in physical activity: a metaanalysis. Scandinavian Journal of Medicine and Science in Sports, 9(6), 315-332. DOI: 10.1111/j.1600-0838.1999.tb00253.x

Ntoumanis, N., Taylor, I., \& ThØgersen-Ntoumani, C. (2012). A longitudinal examination of coach and peer motivational climates in youth sport: Implications for moral attitudes, well-being, and behavioral investment. Developmental Psychology, 48(1), 213-223. DOI: $10.1037 / \mathrm{a} 0024934$. 
Ntoumanis, N. \& Vazou, S. (2005). Peer motivational climate in youth sport: Measurement development and validation. Journal of Sport and Exercise Psychology, 27, 432-455.

Ntoumanis, N., Vazou, S., \& Duda, J. (2007). Peer-created motivational climate. In Jowett, S. \& Lavellee, D (Eds.), Social Psychology in Sport (145-156). Champaign, IL: Human Kinetics.

Ommundsen, Y., Roberts, G., Lemyre, P. N., \& Miller, B. W. (2005). Peer relationships in adolescent competitive soccer: Associations to perceived motivational climate, achievement goals and perfectionism. Journal of Sports Sciences, 23, 977-989.

Papaionannou, A., \& Kouli, O. (1999). The effect of task structure, perceived motivational climate and goal orientations on students' task involvement and anxiety. Journal of Applied Sport Psychology, 11, 51-57.

Pensgaard, A. M., \& Duda, J. L. (2004). Relationship of situational and dispositional goals to coach ratings, perceived stressors and performance among Olympic athletes. Manuscript under review.

Pensgaard, A. M., \& Roberts, G. C. (2002). Elite athletes' experiences of the motivational climate: The coach matters. Scandinavian Journal of Medicine \& Science in Sports, 12(1), 54-59.

Prapavessis, H., \& Carron, A. V. (1996). The effect of group cohesion on competitive state anxiety. Journal of Sport \& Exercise Psychology, 18, 64-74.

Prapavessis, H., \& Carron, A. (1997). Sacrifice, cohesion, and conformity to norms in sport teams. Group Dynamics, 1(3), 231-240. 
Reinboth, M., Duda, J. L., \& Ntoumanis, N. (2004). Dimensions of coaching behavior, need satisfaction, and the psychological and physical welfare of young athletes. Motivation and Emotion, 28, 297-313.

Seifriz, J., Duda, J. \& Likang, C. (1992). The relationship of perceived motivational climate to intrinsic motivation and beliefs about success in basketball. Journal of Sport \& Exercise Psychology, 14(4), 375-391.

Tabachnick, B.G., \& Fidell, L.S. (2013). Using multivariate statistics. Boston: Pearson.

Treasure, D.C. (1993). A social-cognitive approach to understanding children's achievement behavior, cognitions, and affect in competitive sport. Unpublished doctoral dissertation.University of Illinois at Urbana- Champaign.

Vazou, S., Ntoumanis, N. \& Duda, J. (2005). Peer motivational climate in youth sport: a qualitative inquiry. Psychology of Sport and Exercise, 6, 497-516.

Vazou, S., Ntoumanis, N., \& Duda, J. (2006). Predicting young athletes' motivational indices as a function of their perceptions of the coach-and peer-created climate. Psychology of Sport and Exercise, 7(2), 215-233.

Walling, M., Duda, J. L., Chi, L. (1993). The perceived motivational climate in sport questionnaire: construct and predictive validity. Journal of Sport \& Exercise Psychology, 15(2), 172-183.

Zaccaro, S. J., Blair, V., Peterson, C., \& Zazanis, M. (1995). Collective efficacy. In: J. Maddux (Ed.), Self-efficacy, adaptation, and adjustment (pp. 305 - 328). New York: Plenum. 


\section{Athlete Survey}

The purpose of this research study is to understand athletes' sport experiences. This research will help understand motivation athletes have for sport participation and results could improve experiences for athletes in the future.

Your participation in this study is completely voluntary. There are no penalties for choosing not to participate. Further, you may withdraw at any time, for any reason, without penalty.

If you are willing to help us out and participate, please answer the questions on the following pages. By answering the questions you are providing your assent to participate in this study. This survey should take 15-20 minutes to complete.

If you have any questions or concerns about this study please contact the principal investigator (Anthony Amorose, 309-438-8590) and/or Research Ethics and Compliance Office at Illinois State University (309-438-2529) or via email at rec@,IllinoisState.edu. The foreseeable risks association with participation in this research is minimal. Answering this survey may lead to some self-doubt, as some of the questions ask about ability and thoughts about sport participation. There are no direct benefits to the participant, although a brief description of the results of the research will be provided to your coach.

Please note, there are no right or wrong answers, your name is not on this survey, and nobody else will see your responses, so please be as honest as possible!

You are free to keep this page. 


\section{Sport Background}

1. What sport are you currently playing (e.g., soccer)?

2. How many years total have you participated in your current sport? years

3. How many seasons have you been a member of your current team? seasons

4. How long have you been playing for your current coach? years

5. Circle the gender of your coach. male female

Use the sport you listed above and your current coach and teammates as a reference when answering the questions in the survey.

\section{Personal Information}

1. How old are you? years

2. What grade are you in school? grade

3. Circle your gender: male female

4. How would you describe yourself? (circle one)

African

American

Asian

Hispanic

Native

American

White

Other 


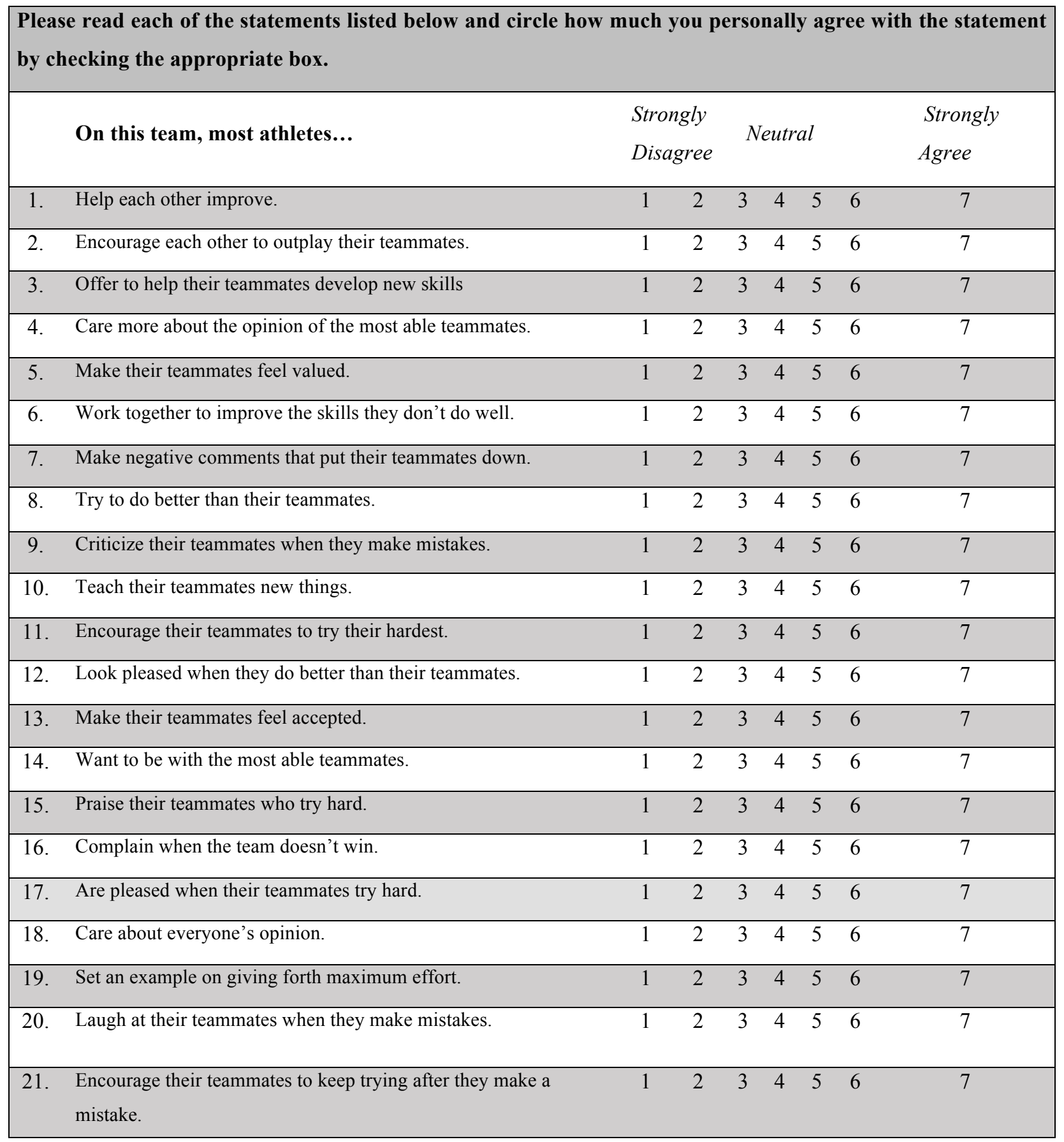

\section{Please Continue on to the Next Page}




\begin{tabular}{|c|c|c|c|c|c|}
\hline \multicolumn{6}{|c|}{$\begin{array}{l}\text { Please read each of the statements listed below and circle how much you personally agree with the statement } \\
\text { by checking the appropriate box. }\end{array}$} \\
\hline On my team... & $\begin{array}{l}\text { Strongly } \\
\text { Disagree }\end{array}$ & Disagree & Neutral & Agree & $\begin{array}{c}\text { Strongly } \\
\text { Agree }\end{array}$ \\
\hline 1. the coach wants us to try new skills & 1 & 2 & 3 & 4 & 5 \\
\hline $\begin{array}{l}\text { 2. the coach gets mad when a player makes a } \\
\text { mistake }\end{array}$ & 1 & 2 & 3 & 4 & 5 \\
\hline $\begin{array}{l}\text { 3. the coach gives most of his/her attention to the } \\
\text { 'stars' }\end{array}$ & 1 & 2 & 3 & 4 & 5 \\
\hline 4. each player contributes in some important way & 1 & 2 & 3 & 4 & 5 \\
\hline $\begin{array}{l}\text { 5. the coach believes that all of us are crucial to the } \\
\text { team's success }\end{array}$ & 1 & 2 & 3 & 4 & 5 \\
\hline $\begin{array}{l}\text { 6. the coach praises players only when they outplay } \\
\text { teammates }\end{array}$ & 1 & 2 & 3 & 4 & 5 \\
\hline $\begin{array}{l}\text { 7. the coach thinks only the starters contribute to the } \\
\text { team's success }\end{array}$ & 1 & 2 & 3 & 4 & 5 \\
\hline 8. $\quad$ players feel good when they try their best & 1 & 2 & 3 & 4 & 5 \\
\hline 9. $\quad$ players are taken out of games for mistakes & 1 & 2 & 3 & 4 & 5 \\
\hline $\begin{array}{l}\text { 10. players at all skill levels have an important role } \\
\text { on the team }\end{array}$ & 1 & 2 & 3 & 4 & 5 \\
\hline 11. players help each other learn & 1 & 2 & 3 & 4 & 5 \\
\hline $\begin{array}{l}\text { 12. players are encouraged to outplay their own } \\
\text { teammates }\end{array}$ & 1 & 2 & 3 & 4 & 5 \\
\hline 13. the coach has his/her favorites & 1 & 2 & 3 & 4 & 5 \\
\hline $\begin{array}{l}\text { 14. the coach makes sure players improve on skills } \\
\text { they're not good at }\end{array}$ & 1 & 2 & 3 & 4 & 5 \\
\hline 15. the coach yells at players for messing up & 1 & 2 & 3 & 4 & 5 \\
\hline 16. players feel successful when they improve & 1 & 2 & 3 & 4 & 5 \\
\hline 17. only the players with the best 'stats' get praise & 1 & 2 & 3 & 4 & 5 \\
\hline 18. players are punished when they make a mistake & 1 & 2 & 3 & 4 & 5 \\
\hline 19. each player has an important role & 1 & 2 & 3 & 4 & 5 \\
\hline 20. trying hard is rewarded & 1 & 2 & 3 & 4 & 5 \\
\hline $\begin{array}{l}\text { 21. the coach encourages players to help each other } \\
\text { learn }\end{array}$ & 1 & 2 & 3 & 4 & 5 \\
\hline
\end{tabular}

\section{Please Continue on to the Next Page.}




\begin{tabular}{|c|c|c|c|c|c|}
\hline On my team... & $\begin{array}{l}\text { Strongly } \\
\text { Disagree }\end{array}$ & Disagree & Neutral & Agree & $\begin{array}{c}\text { Strongly } \\
\text { Agree }\end{array}$ \\
\hline $\begin{array}{l}\text { 22. the coach makes it clear who he/she thinks are the } \\
\text { best players }\end{array}$ & 1 & 2 & 3 & 4 & 5 \\
\hline $\begin{array}{l}\text { 23. players are 'psyched' when they do better than their } \\
\text { teammates }\end{array}$ & 1 & 2 & 3 & 4 & 5 \\
\hline $\begin{array}{l}\text { 24. if you want to play in a game you must be one of the } \\
\text { best players }\end{array}$ & 1 & 2 & 3 & 4 & 5 \\
\hline 25. the coach emphasizes always trying your best & 1 & 2 & 3 & 4 & 5 \\
\hline 26. only the top players 'get noticed' by the coach & 1 & 2 & 3 & 4 & 5 \\
\hline 27. players are afraid to make mistakes & 1 & 2 & 3 & 4 & 5 \\
\hline 28. players are encouraged to work on their weaknesses & 1 & 2 & 3 & 4 & 5 \\
\hline 29. the coach favors some players more than others & 1 & 2 & 3 & 4 & 5 \\
\hline 30. the focus is to improve each game/practice & 1 & 2 & 3 & 4 & 5 \\
\hline 31. the players really 'work together' as a unit & 1 & 2 & 3 & 4 & 5 \\
\hline $\begin{array}{l}\text { 32. each player feels as if they are an important team } \\
\text { member }\end{array}$ & 1 & 2 & 3 & 4 & 5 \\
\hline 33. players help each other to get better and excel & 1 & 2 & 3 & 4 & 5 \\
\hline
\end{tabular}

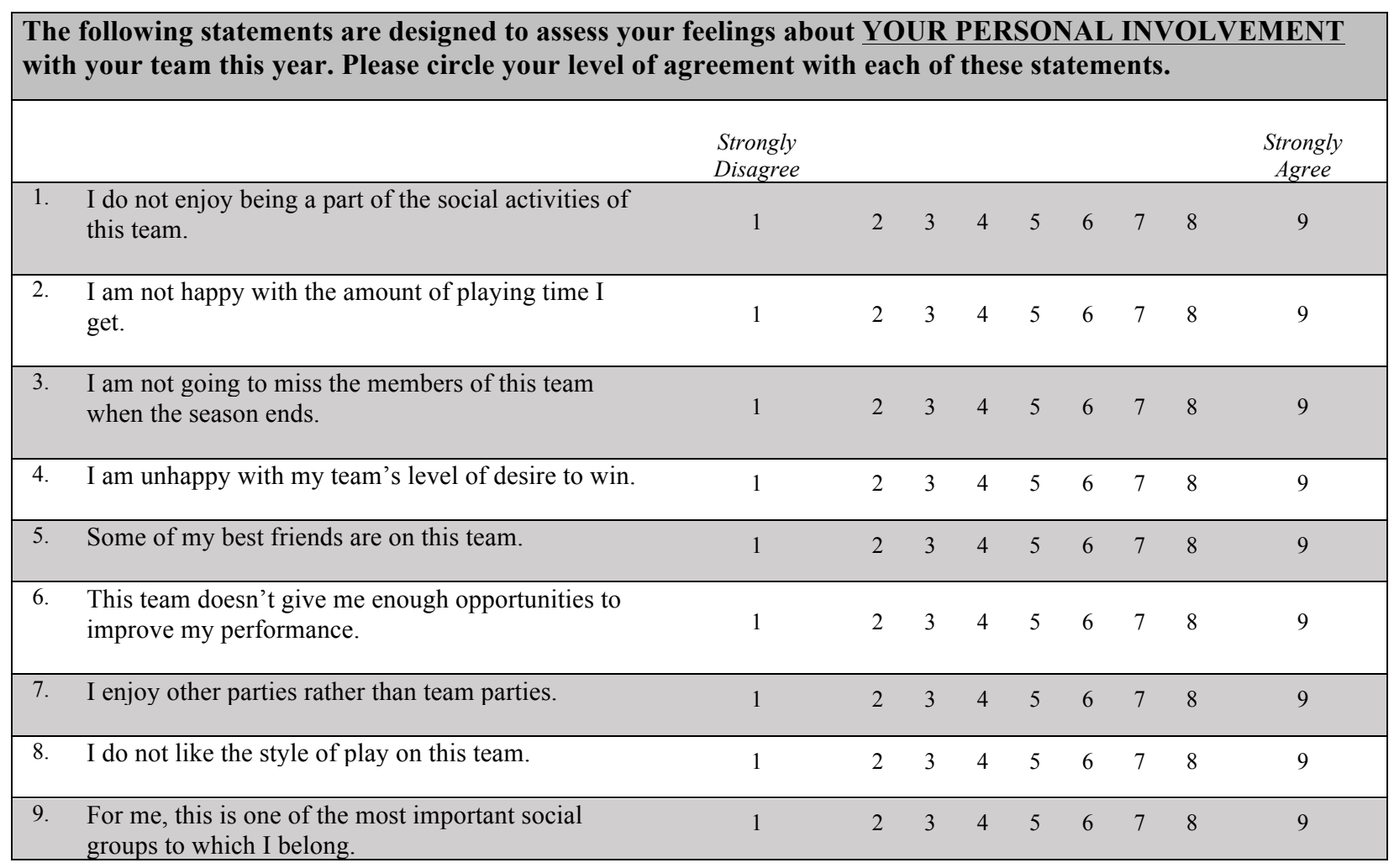

\section{Please Continue on to the Next Page.}




\begin{tabular}{|c|c|c|c|c|c|c|c|c|c|}
\hline \multicolumn{10}{|c|}{$\begin{array}{l}\text { The following statements are designed to assess your perceptions of YOUR TEAM AS A WHOLE. } \\
\text { Please circle your level of agreement with each of these statements. }\end{array}$} \\
\hline & $\begin{array}{l}\text { Strongly } \\
\text { Disagree }\end{array}$ & & & & & & & & $\begin{array}{l}\text { Strongly } \\
\text { Agree }\end{array}$ \\
\hline 1. Our team is united in trying to reach its goals for performance. & 1 & 2 & 3 & 4 & 5 & 6 & 7 & 8 & 9 \\
\hline $\begin{array}{l}\text { 2. Members of our team would rather go out on their own than get } \\
\text { together as a team. }\end{array}$ & 1 & 2 & 3 & 4 & 5 & 6 & 7 & 8 & 9 \\
\hline $\begin{array}{l}\text { 3. We all take responsibility for any loss or poor performance by } \\
\text { our team. }\end{array}$ & 1 & 2 & 3 & 4 & 5 & 6 & 7 & 8 & 9 \\
\hline 4. Our team members rarely party together. & 1 & 2 & 3 & 4 & 5 & 6 & 7 & 8 & 9 \\
\hline $\begin{array}{l}\text { 5. Our team members have conflicting aspirations for the team's } \\
\text { performance. }\end{array}$ & 1 & 2 & 3 & 4 & 5 & 6 & 7 & 8 & 9 \\
\hline 6. Our team would like to spend time together in the off season. & 1 & 2 & 3 & 4 & 5 & 6 & 7 & 8 & 9 \\
\hline $\begin{array}{l}\text { 7. If members of our team have problems in practice, everyone } \\
\text { wants to help them so we can get back together again. }\end{array}$ & 1 & 2 & 3 & 4 & 5 & 6 & 7 & 8 & 9 \\
\hline $\begin{array}{l}\text { 8. Members of our team do not stick together outside practices and } \\
\text { games. }\end{array}$ & 1 & 2 & 3 & 4 & 5 & 6 & 7 & 8 & 9 \\
\hline $\begin{array}{l}\text { 9. Our team members do not communicate freely about each } \\
\text { athlete's responsibilities during competition or practice. }\end{array}$ & 1 & 2 & 3 & 4 & 5 & 6 & 7 & 8 & 9 \\
\hline
\end{tabular}

\section{Please circle the response that best reflects how you feel about your participation in your sport.}

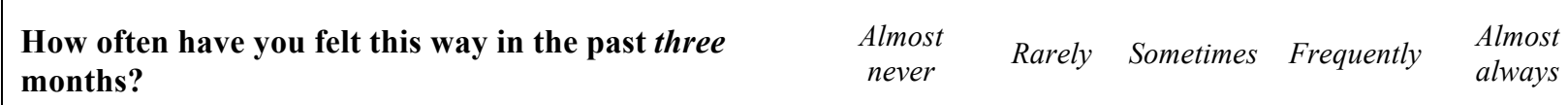

\begin{tabular}{|c|c|c|c|c|c|c|}
\hline 1. & $\begin{array}{l}\text { I believe I am capable of accomplishing my goals in } \\
\text { sport. }\end{array}$ & 1 & 2 & 3 & 4 & 5 \\
\hline 2. & I am dedicated to achieving my goals in sport. & 1 & 2 & 3 & 4 & 5 \\
\hline 3. & I feel energized when I participate in my sport. & 1 & 2 & 3 & 4 & 5 \\
\hline 4. & I feel excited about my sport. & 1 & 2 & 3 & 4 & 5 \\
\hline 5. & I feel capable of success in my sport. & 1 & 2 & 3 & 4 & 5 \\
\hline 6. & I am determined to achieve my goals in sport. & 1 & 2 & 3 & 4 & 5 \\
\hline 7. & I feel energetic when I participate in my sport. & 1 & 2 & 3 & 4 & 5 \\
\hline 8. & I am enthusiastic about my sport. & 1 & 2 & 3 & 4 & 5 \\
\hline 9. & $\begin{array}{l}\text { I believe I have the skills/technique to be successful in } \\
\text { my sport. }\end{array}$ & 1 & 2 & 3 & 4 & 5 \\
\hline 10. & I am devoted to my sport. & 1 & 2 & 3 & 4 & 5 \\
\hline 11. & I feel really alive when I participate in my sport. & 1 & 2 & 3 & 4 & 5 \\
\hline
\end{tabular}

\section{Please Continue on to the Next Page.}




\begin{tabular}{|l|ccccc|}
\hline $\begin{array}{l}\text { How often have you felt this way in the past three } \\
\text { months? }\end{array}$ & $\begin{array}{c}\text { Almost } \\
\text { never }\end{array}$ & Rarely & Sometimes & Frequently & $\begin{array}{c}\text { Almost } \\
\text { always }\end{array}$ \\
\hline $12 . \quad$ I enjoy my sport. & 1 & 2 & 3 & 4 & 5 \\
\hline $13 . \quad$ I am confident in my abilities. & 1 & 2 & 3 & 4 & 5 \\
\hline $14 . \quad$ I want to work hard to achieve my goals in sport. & 1 & 2 & 3 & 4 & 5 \\
\hline $15 . \quad$ I feel mentally alert when I participate in my sport & 1 & 2 & 3 & 4 & 5 \\
\hline $16 . \quad$ I have fun in my sport. & 1 & 2 & 3 & 4 & 5 \\
\hline
\end{tabular}

\begin{tabular}{|c|c|c|c|c|c|c|c|}
\hline \multicolumn{8}{|c|}{$\begin{array}{l}\text { Please consider your thoughts and feeling about your current sport and circle the number for the degree to } \\
\text { which each of the following statements corresponds to you. }\end{array}$} \\
\hline \multicolumn{7}{|c|}{ Not At All Like Me } & \multirow{2}{*}{$\begin{array}{c}\text { Completel } \\
\text { Like Me } \\
7\end{array}$} \\
\hline 1. It is important to me to perform as well as I possibly can. & 1 & 2 & 3 & 4 & 5 & 6 & \\
\hline 2. I worry that I may not perform as well as I possibly can. & 1 & 2 & 3 & 4 & 5 & 6 & 7 \\
\hline 3. It is important for me to do well compared to others. & 1 & 2 & 3 & 4 & 5 & 6 & 7 \\
\hline 4. I just want to avoid performing worse than others. & 1 & 2 & 3 & 4 & 5 & 6 & 7 \\
\hline 5. I want to perform as well as it is possible for me to perform. & 1 & 2 & 3 & 4 & 5 & 6 & 7 \\
\hline $\begin{array}{l}\text { 6. Sometimes I am afraid that I may not perform as well as I'd } \\
\text { like. }\end{array}$ & 1 & 2 & 3 & 4 & 5 & 6 & 7 \\
\hline 7. It is important for me to perform better than others. & 1 & 2 & 3 & 4 & 5 & 6 & 7 \\
\hline 8. My goal is to avoid performing worse than everyone else. & 1 & 2 & 3 & 4 & 5 & 6 & 7 \\
\hline 9. It is important for me to master all aspects of my performance. & 1 & 2 & 3 & 4 & 5 & 6 & 7 \\
\hline $\begin{array}{l}\text { 10. I'm often concerned that I may not perform as well as I can } \\
\text { perform. }\end{array}$ & 1 & 2 & 3 & 4 & 5 & 6 & 7 \\
\hline 11. My goal is to do better than most other performers. & 1 & 2 & 3 & 4 & 5 & 6 & 7 \\
\hline $\begin{array}{l}\text { 12. It is important for me to avoid being one of the worst } \\
\text { performers in the group. }\end{array}$ & 1 & 2 & 3 & 4 & 5 & 6 & 7 \\
\hline
\end{tabular}

\section{Please Continue on to the Next Page.}


Please circle the response that best reflects how you feel about your participation in your sport.

\begin{tabular}{|c|c|c|c|c|c|}
\hline & $\begin{array}{l}\text { Almost } \\
\text { Never }\end{array}$ & Rarely & Sometimes & Frequently & $\begin{array}{l}\text { Almost } \\
\text { Always }\end{array}$ \\
\hline 1. I'm accomplishing many worthwhile things in my sport & 1 & 2 & 3 & 4 & 5 \\
\hline $\begin{array}{l}\text { 2. I feel so tired from my training that I have trouble finding energy to } \\
\text { do other things }\end{array}$ & 1 & 2 & 3 & 4 & 5 \\
\hline $\begin{array}{l}\text { 3. The effort I spend in my sport would be better spent doing other } \\
\text { things }\end{array}$ & 1 & 2 & 3 & 4 & 5 \\
\hline 4. I feel overly tired from my sport participation & 1 & 2 & 3 & 4 & 5 \\
\hline 5. I am not achieving much in my sport & 1 & 2 & 3 & 4 & 5 \\
\hline 6. I don't care as much about my sport performance as I used to & 1 & 2 & 3 & 4 & 5 \\
\hline 7. I am not performing up to my ability in my sport & 1 & 2 & 3 & 4 & 5 \\
\hline 8. I feel "wiped out" from my sport & 1 & 2 & 3 & 4 & 5 \\
\hline 9. I am not into my sport like I used to be & 1 & 2 & 3 & 4 & 5 \\
\hline 10. I feel physically worn out from my sport & 1 & 2 & 3 & 4 & 5 \\
\hline $\begin{array}{l}\text { 11. I feel less concerned about being successful in my sport than I used } \\
\text { to }\end{array}$ & 1 & 2 & 3 & 4 & 5 \\
\hline 12. I am exhausted by the mental and physical demands of my sport & 1 & 2 & 3 & 4 & 5 \\
\hline 13. It seems that no matter what I do, I don't perform as well as I should & 1 & 2 & 3 & 4 & 5 \\
\hline 14. I feel successful at my sport & 1 & 2 & 3 & 4 & 5 \\
\hline 15. I have negative feelings toward my sport & 1 & 2 & 3 & 4 & 5 \\
\hline
\end{tabular}

